\title{
Investigation of the central and peripheral analgesic and anti-inflammatory activity of Draksharishta an Indian Ayurvedic formulation
}

\begin{abstract}
Rationale: Draksharishta (DRK) is an Ayurvedic formulation approved by the "National formulary of Ayurvedic Medicine 2011", of Bangladesh. It is widely available in the Bangladeshi market as an effective preparation to treat lumbago, sciatia and arthritic pain of joints. But there are very scientific evidences available to support their common uses. Objectives: Our present studies make an attempt toward identifying probable antinociceptive and anti-inflammatory effect and its mechanisms of DRK. Findings: DRK, at three doses, $(10 \mathrm{~mL} / \mathrm{kg}, 20 \mathrm{~mL} / \mathrm{kg}$, and $40 \mathrm{~mL} / \mathrm{kg}$ ) showed no involvement of the CNS in antinociceptive activity of the test drug. Both Carrageenaninduced paw edema and acetic acid writhing tests gave significant results $(P<0.05)$, indicating possible peripheral analgesic and anti-inflammatory action. Formalin-induced paw- licking test showed that DRK had significant effect in suppressing inflammatory pain $(P<0.05)$ but not neurogenic pain. Conclusions: Hence our study shows anti-inflammatory and peripheral analgesic action for DRK.
\end{abstract}

Key words:

Anti-inflammatory, anti-nociceptive, central analgesic, Draksharishta, peripheral analgesic

\section{Introduction}

World Health Organization (WHO) has stated that up to 80\% of the population in many Asian and African countries depend on traditional and complimentary drugs to meet their medical necessities. ${ }^{[1]}$ It is also an extremely attractive business for many drug vendors which often results in misleading claims being made and confusion in the mind of consumers. Persistent continuation of a regimen with one of these drugs which do not have any pharmacological activity, in reality, would seriously aggravate the morbidity of the patients. For these reasons and others, there has been a demand for ensuring the safety and efficacy of some of these traditional/ herbal medicines ${ }^{[2]}$ Under the status quo, these products are often sold under hyperbolic and outrageous claims without much scientific evidences. ${ }^{[3]}$ In this paper, we analyzed the analgesic and anti-inflammatory property of Draksharishta (DRK), a commonly available herbal product licensed under the Directorate General of Drug Administration (DGDA) of Bangladesh.

\begin{tabular}{|c|c|}
\hline \multicolumn{2}{|c|}{ Access this article online } \\
\hline & Quick Response Code \\
\hline $\begin{array}{l}\text { Website: } \\
\text { www.jbclinpharm.org }\end{array}$ & 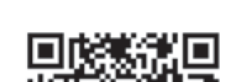 \\
\hline $\begin{array}{l}\text { DOI: } \\
10.4103 / 0976-0105.105335\end{array}$ & 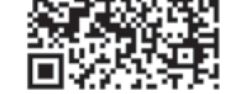 \\
\hline
\end{tabular}

Pain has been defined by The International Association for the Study of Pain as an unpleasant sensory and emotional experience associated with actual or potential tissue damage. ${ }^{[4]}$ This process enables an individual to take protective measures, by providing with rapid awareness about threatening or potentially threatening injury. ${ }^{[5]}$ However, if the painful sensation remains after removal of the detectable stimulus, it calls for a regimen for pain management. ${ }^{[6]}$

DRK is included in the Bangladesh National Formulary of Ayurvedic Medicine 2011 (2 ${ }^{\text {nd }}$ Ed.). ${ }^{[7]}$ It is primarily indicated in rheumatoid arthritis, lumbago (low-back pain) and sciatica (pain which may arise from compression and/or irritation of one of five spinal nerve roots which give rise to each sciatic nerve). ${ }^{[7]}$ We have used the following in vivo animal models to test the analgesic and anti-inflammatory effect of the test drug: Hot Plate test, Tail Immersion test, Formalin-induced Paw licking, Carrageenan-induced Paw Edema test, Acetic Acid Writhing test.

Ashraf-ul Kabir, Mehdi Bin Samad, Ninadh Malrina D'Costa, Juardar Mohammad Hannan Department of Pharmacy, North South University, Dhaka, Bangladesh

Address for correspondence: Mr. Ashraf-ul Kabir, House-133, Road-6, Block-C, bashundhara R/A, Dhaka, Bangladesh. E-mail:ashraful_kabir@ymail.com 


\section{Materials and Methods}

\section{Reagents used}

All reagents and chemicals that were used in the experiments were of analytical grade. DRK was procured from University Ayurvedic Research Centre, Jahangirnagar University, Savar, Bangladesh. Pharmaceutical grade Tramadol, and Diclofenac Sodium were collected from Square Pharmaceuticals Bangladesh Ltd. All other reagents were procured from Sigma Aldrich (USA) unless mentioned otherwise.

\section{Dose and route of administration}

$0.9 \% \mathrm{NaCl}$ was administered to the animals per oral (p.o.) at a volume that would not cause any additional psychological or physiological stress to the animals. For experimental purpose $10 \mathrm{~mL} / \mathrm{kg}, 20 \mathrm{~mL} / \mathrm{kg}$, and $40 \mathrm{~mL} / \mathrm{kg}$ doses of DRK were used. The drug proved to be nonlethal at all doses in previous toxicity screening studies.

\section{Maintenance and use of test animals}

Healthy Swiss Albino mice (5-6 weeks old, of both sex) weighing 20-25 $\mathrm{g}$ and Spraugue-Dawley rats, weighing 130-160 g, were procured from Jahangir Nagar University Animal House. The test subjects were provided with standard rat pellet diet and filtered drinking water ad libitum. This study was approved by an ethics committee of North South University which gave its consent in absolute accordance with the recommendations of the International Association for the study of Pain. ${ }^{[8]}$

\section{Grouping and drug administration}

The animals were randomly divided into several groups of 8 mice/rats for the planned analgesic and anti-inflammatory tests. Control groups were treated p.o. with $0.9 \% \mathrm{NaCl}$. Positive controls were treated with Tramadol and Diclofenac Sodium. Treatment groups were treated with three doses (10 $\mathrm{mL} / \mathrm{kg}, 20 \mathrm{~mL} / \mathrm{kg}$, and $40 \mathrm{~mL} / \mathrm{kg}$ ) of DRK.

\section{Determination of CNS modulation in analgesic activity \\ Hot plate test}

The Hot plate test was performed on the test subjects in a slightly modified version from the one described earlier. ${ }^{[9]}$ The animals were placed on hot plate apparatus (Model-3510o, manufacturer-UGO Basile of Italy) maintained at a temperature of $54 \pm 0.5^{\circ} \mathrm{C}$ for a maximum time of $20 \mathrm{~s}$ per exposure. The control group was administered with $0.9 \%$ $\mathrm{NaCl}$ p.o. The treatment groups were treated with DRK (10 $\mathrm{mL} / \mathrm{kg}, 20 \mathrm{~mL} / \mathrm{kg}$, and $40 \mathrm{~mL} / \mathrm{kg}$ p.o.). Naloxone $(5 \mathrm{mg} / \mathrm{kg}$ i.p.) was administered with DRK (10 mL/ kg, $20 \mathrm{~mL} / \mathrm{kg}$, and $40 \mathrm{~mL} / \mathrm{kg}$ p.o.) and Tramadol to four different groups, other than the treatment groups.

\section{Tail immersion test}

The tail immersion test was performed according to the procedures used by Yang et al., ${ }^{[10]}$ with minor modifications. Briefly, the lower two-third of mouse's tail was immersed in a constant temperature water bath at $50 \pm 0.2^{\circ} \mathrm{C}$. The reaction time, i.e., the amount of time it takes the animal to withdraw its tail was measured. DRK (10 mL/kg, $20 \mathrm{~mL} / \mathrm{kg}$, and $40 \mathrm{~mL} /$ kg p.o.), Tramadol (10 mg/kg p.o.), and o.9\% $\mathrm{NaCl}$ (p.o.) were administered to treatment groups. Naloxone ( $5 \mathrm{mg} / \mathrm{kg}$ i.p.) was administered with DRK (10 mL/ $\mathrm{kg}, 20 \mathrm{~mL} / \mathrm{kg}$, and 40 $\mathrm{mL} / \mathrm{kg}$ p.o.) and Tramadol to four different groups, other than the treatment groups.

\section{Determination of peripheral analgesia Acetic-acid induced writhing test}

The test was carried out using a modified method from the procedure previously described. ${ }^{[11]}$ DRK at three doses (10 $\mathrm{mL} / \mathrm{kg}, 20 \mathrm{~mL} / \mathrm{kg}$, and $40 \mathrm{~mL} / \mathrm{kg}$ p.o.) were administered to treatment groups. Positive control group was administered with Diclofenac sodium (10 mg/kg p.o.) and $0.9 \% \mathrm{NaCl}$ p.o. was administered to the control group. Forty-five minutes after drug treatment, the mice were given $0.7 \% \mathrm{v} / \mathrm{v}$ acetic acid (o.15 mL/10 mL i.p.) to induce writhing.

\section{Carrageenan-induced paw edema test}

Carrageenan-induced paw edema test was carried out by following the method described previously. ${ }^{[12]}$ Male and female Spraugue-Dawley rats were used. The control rats received $0.9 \% \mathrm{NaCl}$ p.o. and the experimental rats received DRK (10 $\mathrm{mL} / \mathrm{kg}, 20 \mathrm{~mL} / \mathrm{kg}$, and $40 \mathrm{~mL} / \mathrm{kg}$ p.o.). Thirty minutes later, the rats were given a subcutaneous injection of $0.05 \mathrm{~mL}$ of $1 \%$ solution of carrageenan.

\section{Dissociation between CNS and peripheral analgesic activity}

\section{Formalin-induced paw-licking test}

The experimental mice were randomly assigned to six groups; each group had eight mice. The formalin test was conducted based on the method of Tjølsen et al. ${ }^{[13]}$ For the formalin test, groups of mice were treated p.o. with $\mathrm{NaCl}(0.9 \% \mathrm{w} / \mathrm{v})$ (for control), DRK at three doses $(10 \mathrm{~mL} / \mathrm{kg}, 20 \mathrm{~mL} / \mathrm{kg}$, and 40 $\mathrm{mL} / \mathrm{kg}$ p.o.) (for treatment group), Tramadol (10 mg/kg i.p.), and Diclofenac Sodium (10 mg/kg i.p.) (both for positive control). Tramadol was used as the positive control drug for both nurogenic phase and inflammatory phases. Diclofenac $\mathrm{Na}$ was used as the positive control drug for the later inflammatory phase.

Naloxone (5 mg/kg i.p.) was administered with DRK (10 $\mathrm{mL} / \mathrm{kg}, 20 \mathrm{~mL} / \mathrm{kg}$, and $40 \mathrm{~mL} / \mathrm{kg}$ p.o.) and Tramadol to four different groups, other than the treatment groups. Percentage inhibition was obtained by using this formula: ${ }^{[14]}$

$$
\frac{\mathrm{T}_{\mathrm{o}}-\mathrm{T}_{\mathrm{t}}}{\mathrm{T}_{\mathrm{o}}} \times 100
$$

$\mathrm{T}_{0}=$ mean licking time for the control group

$\mathrm{T}_{\mathrm{t}}=$ mean licking time for the test group

\section{Statistical analysis}

Results were expressed as mean \pm SEM (standard error of mean) of responses. All tests were done using SPSS Software Ver. 20. For Hot Plate test, Tail Immersion test, and Carrageenan-induced Rat Paw Edema test, Statistical significance was determined by Repeated Measures One-way Analysis of Variance (ANOVA) followed by post hoc Dunnett test. Later, Pair-wise comparison test along with Bonferroni correction were done. For Acetic acid-induced writhing test 
and Formalin test, Statistical significance was determined by One-way Analysis of Variance (ANOVA) followed by post hoc Dunnett test. Then Pair-wise comparison test along with Bonferroni correction were done. The P-values less than 0.05 were considered to be significant.

\section{Result}

\section{Hot-plate test}

In the Hot Plate Test, DRK treatment caused no significant increase in analgesia. In the presence of Naloxone, an antagonist of opioid receptor, the effect of Tramadol was reduced profoundly as shown in Table 1.

\section{Tail immersion test}

Table 2 shows that the analgesic effect of DRK was also not significant in Tail immersion test. DRK failed to induce any "tail flick antinociceptive" index.

\section{Acetic acid-induced writhing test}

Intraperitoneal injection of $0.7 \%$ acetic acid given to the control group caused $16.83 \pm 0.87$ writhes in a 5 -minute interval. The treatment with DRK induced a significant decrease, with a 43.56\% ( $\mathrm{P}<0.05)$ inhibition observed in the $20 \mathrm{~mL} / \mathrm{kg}$ group and $84.16 \%(\mathrm{P}<0.01)$ in the $40 \mathrm{~mL} / \mathrm{kg}$ group [Figure 1].

\section{Carrageenan induced paw edema test}

The injection of carrageenan at rat paw created an edema that increased gradually [Table 3]. DRK $20 \mathrm{~mL} / \mathrm{kg}$ showed $20.80 \%$ and $23.10 \%$ reduction in the volume of the edematous paw at $4 \mathrm{~h}$ and $5 \mathrm{~h}$ after carrageenan injection, respectively. Whereas, DRK $40 \mathrm{~mL} / \mathrm{kg}$ showed significant anti-inflammatory activity starting from $2 \mathrm{~h}$ after the injection of carrageenan to throughout the experiment time with a highest reduction of $36.20 \%$ ( $5 \mathrm{~h}$ after the carrageenan injection).

\section{Formalin-induced paw-licking test}

In the Formalin-induced paw-licking test, DRK treated mice groups except $10 \mathrm{~mL} / \mathrm{kg}$ group showed significant activities in the later phase pain responses $(20 \mathrm{~mL} / \mathrm{kg} 65.06 \%$ and $40 \mathrm{~mL} / \mathrm{kg} \mathrm{79.66 \% )} \mathrm{compared} \mathrm{to} \mathrm{that} \mathrm{of} \mathrm{the} \mathrm{control} \mathrm{group}$ [Table 4]. All three doses $(10 \mathrm{~mL} / \mathrm{kg}, 20 \mathrm{~mL} / \mathrm{kg}$, and $40 \mathrm{~mL} /$ $\mathrm{kg}$ ) of DRK failed to induce any significant analgesic activity at early phase of the experiment. In combination studies using Naloxone, an antagonist of opioid receptor, the analgesic activity of the Tramadol was diminished in both phases. The analgesic activity of Diclofenac $\mathrm{Na}$ was not diminished by the co-treatment with Naloxone. Cotreatment with naloxone also did not affect the analgesic activity of DRK in the later phase of the experiment, suggesting that there might be no involvement of opioid receptor in the analgesic activity of DRK.

\section{Discussion}

Two well-known models of thermal nociception, hot-plate test and tail immersion test were employed to double check on possible involvement of spinal, supraspinal pathways, and $\mathrm{m}$-opiate receptor agonism in regulation (CNS modulation) of pain response by DRK. Our findings demonstrated no activity of in either model. Hence, probable involvement of the central nervous system, in this case, could be ruled out.

To reinforce the above findings, we employed the formalin induced paw-licking test. This test is capable of discerning

\begin{tabular}{|c|c|c|c|c|c|c|c|c|}
\hline \multirow[t]{2}{*}{ Group } & \multirow[t]{2}{*}{ Dose } & \multicolumn{7}{|c|}{ Latency period (second) } \\
\hline & & $0 \mathrm{~min}$ & $30 \mathrm{~min}$ & 1h & $2 h$ & $3 h$ & $4 h$ & $5 h$ \\
\hline Control & - & $10.40 \pm 0.3$ & $10.72 \pm 2.0$ & $10.62 \pm 2.2$ & $10.95 \pm 2.1$ & $10.96 \pm 2.1$ & $8.53 \pm 2.1$ & $9.22 \pm 1.9$ \\
\hline DRK & $10 \mathrm{~mL} / \mathrm{Kg}$ & $11.53 \pm 0.7$ & $7.07 \pm 0.8$ & $7.93 \pm 1.0$ & $8.30 \pm 0.9$ & $7.50 \pm 1.4$ & $7.18 \pm 0.6$ & $6.92 \pm 1.0$ \\
\hline DRK & $20 \mathrm{~mL} / \mathrm{kg}$ & $10.52 \pm 0.8$ & $8.25 \pm 0.8$ & $7.70 \pm 1.1$ & $6.30 \pm 1.0$ & $6.13 \pm 1.1$ & $4.90 \pm 0.8$ & $3.77 \pm 0.8$ \\
\hline DRK & $40 \mathrm{~mL} / \mathrm{kg}$ & $13.35 \pm 0.5$ & $8.50 \pm 0.7$ & $8.50 \pm 0.9$ & $8.60 \pm 0.7$ & $7.73 \pm 0.8$ & $4.90 \pm 1.1$ & $3.81 \pm 0.6$ \\
\hline Tramadol & $10 \mathrm{mg} / \mathrm{kg}$ & $10.90 \pm 0.4$ & $18.67 \pm 2.3^{*}$ & $19.83 \pm 2.5^{\ddagger}$ & $19.33 \pm 2.1^{\ddagger}$ & $19.13 \pm 2.1^{\ddagger}$ & $19.67 \pm 2.1^{\ddagger}$ & $19.78 \pm 1.9$ \\
\hline
\end{tabular}

Values are expressed as Mean \pm S.E.M $(n=8)$. Differences between groups are determined by One-Way Repeated Measures ANOVA followed by post hoc Dunnett test; later pair-wise comparison tests were done with Bonferroni correction. ${ }^{*} P<0.05$ and ${ }^{\ddagger} P<0.01$ compared to the control group

\section{Table 2: Effect of DRK on nociceptive responses in the tail immersion test}

\begin{tabular}{lcccccc} 
Group & Dose & \multicolumn{5}{c}{ Latency period (second) } \\
\cline { 3 - 7 } & & $\mathbf{0}$ min & $\mathbf{3 0} \mathbf{~ m i n}$ & $\mathbf{6 0} \mathbf{m i n}$ & $\mathbf{9 0} \mathbf{m i n}$ & $\mathbf{1 2 0} \mathbf{m i n}$ \\
Control & - & $7.33 \pm 1.81$ & $3.25 \pm 2.21$ & $4.92 \pm 2.91$ & $3.75 \pm 2.01$ & $3.83 \pm 2.59$ \\
DRK & $10 \mathrm{~mL} / \mathrm{kg}$ & $3.12 \pm 2.10$ & $5.00 \pm 1.87$ & $3.32 \pm 2.00$ & $3.15 \pm 0.99$ & $4.10 \pm 1.33$ \\
DRK & $20 \mathrm{~mL} / \mathrm{kg}$ & $3.30 \pm 1.66$ & $4.10 \pm 2.43$ & $5.57 \pm 1.78$ & $4.58 \pm 1.79$ & $7.03 \pm 1.77$ \\
DRK & $40 \mathrm{~mL} / \mathrm{kg}$ & $3.57 \pm 2.06$ & $6.23 \pm 2.43$ & $6.20 \pm 2.43$ & $5.68 \pm 1.84$ & $5.32 \pm 2.04$ \\
Tramadol & $10 \mathrm{mg} / \mathrm{kg}$ & $3.83 \pm 1.81$ & $21.83 \pm 2.21^{\ddagger}$ & $21.90 \pm 2.91^{\ddagger}$ & $20.33 \pm 2.01^{\ddagger}$ & $17.67 \pm 2.59^{\ddagger}$ \\
\hline
\end{tabular}

Values are expressed as Mean \pm S.E.M. Differences between groups are determined by One-Way Repeated Measures ANOVA followed by post hoc Dunnett test; and then pair-wise comparison tests were done with Bonferroni correction. ${ }^{*} P<0.05$ and ${ }^{\ddagger} P<0.01$ compared to the controltreated group 
between nurogenic pain (early phase, acute, non-inflammatory and CNS modulated) and inflammatory (chronic and peripheral pain). ${ }^{\left[5^{-17}\right]}$ The neurogenic pain (first phase) is caused by direct chemical stimulation of nociceptive afferent fibers (predominantly $\mathrm{C}$ fibers) which can be suppressed by opiate like morphine. ${ }^{[18]}$ The inflammatory pain (second phase) is caused by the release of inflammatory mediators like histamine, prostaglandins, bradykinin, serotonin in the peripheral tissues, ${ }^{[19]}$ and from functional changes in the spinal dorsal horn. ${ }^{[20]}$ Our results showed that DRK had no effect on neurogenic pain suppression (first phase) but had

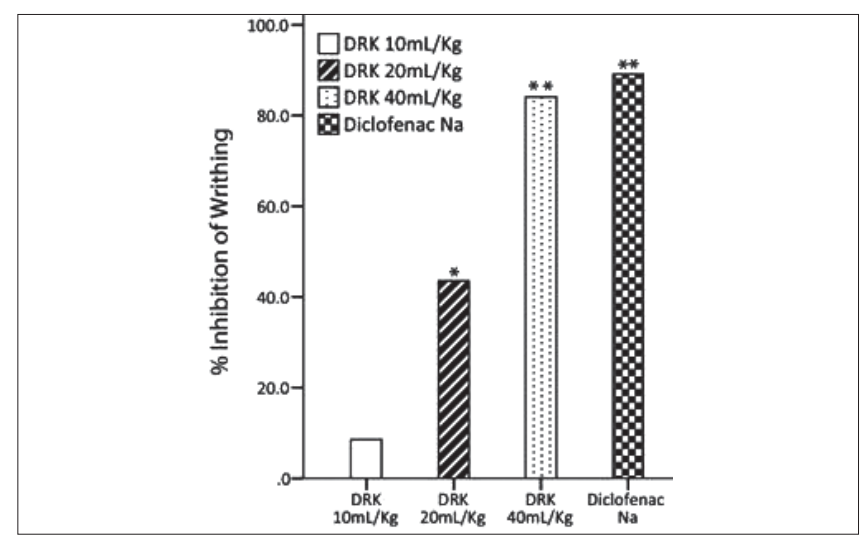

Figure 1: \% Inhibition of writhing in 5-min interval by DRK $(10,20$, and $40 \mathrm{~mL} / \mathrm{kg}$ ) and Diclofenac Na in Acetic acid-induced writhing test. ${ }^{*} P<0.05$ and ${ }^{\ddagger} P<0.01$ compared to the control group effective antinociceptive effect in the peripheral inflammatory (second phase) pain. Cotreatment with naloxone partially blocked the activity of Tramadol in both the phases while that of DRK and Diclofenac Sodium remained unaffected. Hence, we have definitive evidence to conclude that DRK has no CNSmodulated pain suppression activity; however, probably has significant peripheral analgesic and anti-inflammatory effect.

To further ascertain its anti-inflammatory activity, we performed the Acetic Acid-induced writhing test and carrageenan-induced paw edema test. Carrageenan-induced edema is commonly used as an experimental model for acute inflammation, and is proven to be biphasic. ${ }^{[21]}$ The early phase (1-2 hours) of the carrageenan model is chiefly mediated by serotonin and histamine release and increased synthesis of prostaglandins in the damaged paw tissues. These induce inflammation and paw swelling. The later phase is sustained by prostaglandin release and is also mediated by bradykinin, leukotrienes, poly-morphonuclear cells, and prostaglandins produced by tissue macrophages. ${ }^{[22]}$ DRK showed, in a dosedependent manner, significant peripheral analgesic activity at the end of the early phase (2h) and throughout the later phase indicating its possible ability to hinder endogenous synthesis or release of inflammatory mediators such as prostaglandins, histamine, serotonin, bradykinin and leukotrienes.

The acetic acid induced writhing test was carried out to confirm the peripheral analgesic activity of DRK. The acetic acid used in this test increased the prostaglandin level (mainly

\section{Table 3: Effect of DRK on anti-inflammatory responses in carrageenan-induced rat paw edema test}

\begin{tabular}{|c|c|c|c|c|c|c|c|c|}
\hline \multirow[t]{2}{*}{ Group } & \multirow[t]{2}{*}{ Dose } & \multicolumn{7}{|c|}{ Volume of paw } \\
\hline & & $0 \mathrm{~min}$ & $30 \mathrm{~min}$ & $1 \mathrm{~h}$ & $2 \mathrm{~h}$ & $3 \mathrm{~h}$ & $4 \mathrm{~h}$ & $5 \mathrm{~h}$ \\
\hline Control & - & $0.80 \pm 0.02$ & $0.94 \pm 0.09$ & $1.02 \pm 0.09$ & $1.16 \pm 0.11$ & $1.20 \pm 0.06$ & $1.25 \pm 0.09$ & $1.30 \pm 0.09$ \\
\hline DRK & $10 \mathrm{ml} / \mathrm{kg}$ & $0.77 \pm 0.05$ & $0.98 \pm 0.02$ & $0.99 \pm 0.03$ & $1.05 \pm 0.11$ & $1.09 \pm 0.10$ & $1.12 \pm 0.08$ & $1.16 \pm 0.02$ \\
\hline DRK & $20 \mathrm{ml} / \mathrm{kg}$ & $0.79 \pm 0.04$ & $1.03 \pm 0.06$ & $0.93 \pm 0.03$ & $0.94 \pm 0.11$ & $0.98 \pm 0.11$ & $0.99 \pm 0.09 *$ & $1.00 \pm 0.06^{*}$ \\
\hline DRK & $40 \mathrm{ml} / \mathrm{kg}$ & $0.77 \pm 0.02$ & $0.96 \pm 0.06$ & $0.92 \pm 0.10$ & $0.90 \pm 0.09 *$ & $0.92 \pm 0.14^{*}$ & $0.90 \pm 0.13^{*}$ & $0.83 \pm 0.04 *$ \\
\hline Diclofenac $\mathrm{Na}$ & 10 mg/kg & $0.76 \pm 0.05$ & $0.94 \pm 0.03$ & $0.95 \pm 0.21$ & $0.90 \pm 0.14^{*}$ & $0.89 \pm 0.11^{*}$ & $0.85 \pm 0.12^{*}$ & $0.78 \pm 0.09 *$ \\
\hline
\end{tabular}

Values are expressed as Mean \pm S.E.M. $(n=8)$. Differences between groups are determined by One-Way Repeated Measures ANOVA followed by post hoc Dunnett test; and then pair-wise comparison tests were done with Bonferroni correction. ${ }^{*} P<0.05$ compared to the control-treated group

Table 4: Effect of DRK on nociceptive response in the formalin test

\begin{tabular}{|c|c|c|c|c|c|}
\hline \multirow[t]{2}{*}{ Treatment Group } & \multirow[t]{2}{*}{ Dose } & \multicolumn{2}{|c|}{ Early phase } & \multicolumn{2}{|c|}{ Later phase } \\
\hline & & Licking time (s) & Inhibition (\%) & Licking time (s) & Inhibition (\%) \\
\hline Control & - & $84.50 \pm 12.79$ & - & $43.42 \pm 13.50$ & - \\
\hline DRK & $10 \mathrm{~mL} / \mathrm{kg}$ & $71.50 \pm 10.33$ & 15.38 & $33.67 \pm 2.64$ & 22.46 \\
\hline DRK & $20 \mathrm{~mL} / \mathrm{kg}$ & $67.33 \pm 9.94$ & 20.32 & $15.17 \pm 0.91^{*}$ & $65.06^{*}$ \\
\hline DRK & $40 \mathrm{~mL} / \mathrm{kg}$ & $69.50 \pm 10.67$ & 17.75 & $8.83 \pm 1.11^{* *}$ & $79.66^{* *}$ \\
\hline Tramadol & $10 \mathrm{mg} / \mathrm{kg}$ & $4.17 \pm 1.49^{* *}$ & $95.07 * *$ & $4.50 \pm 0.764^{* *}$ & $89.64 * *$ \\
\hline Diclofenac $\mathrm{Na}$ & $10 \mathrm{mg} / \mathrm{kg}$ & $62.50 \pm 8.65$ & 26.04 & $5.50 \pm 1.88^{* *}$ & $87.33^{* *}$ \\
\hline \multicolumn{6}{|l|}{ Cotreatment with naloxone } \\
\hline DRK + Naloxone & $40 \mathrm{~mL} / \mathrm{kg}$ & $79.00 \pm 11.25$ & 6.50 & $8.33 \pm 0.83^{* *}$ & $80.82 * *$ \\
\hline Tramadol + Naloxone & 10 mg/kg & $67.83 \pm 8.10$ & 19.72 & $36.50 \pm 4.18$ & 15.94 \\
\hline Diclofenac $\mathrm{Na}$ + Naloxone & $10 \mathrm{mg} / \mathrm{kg}$ & $71.83 \pm 5.87$ & 15.00 & $4.83 \pm 1.08^{* *}$ & $88.88 * *$ \\
\hline
\end{tabular}

Values are expressed as Mean \pm S.E.M. Differences between groups are determined by One-Way ANOVA followed by post hoc Dunnett test. ${ }^{*} P<0.05$ and ${ }^{*} P<0.01$ compared to the control-treated group 
$\mathrm{PGE}_{2}$ ) in the peritoneal fluid of the mice. ${ }^{[23]}$ Prostaglandins induce abdominal constriction by activating and sensitizing the peripheral chemo-sensitive nociceptors ${ }^{[19]}$ which are mostly responsible for causing inflammatory pain. ${ }^{[24]}$ In our study, DRK, significantly attenuated the writhing in mice in response to acetic acid administration (i.p.), although to a slightly lesser extent compared to the highly potent diclofenac sodium. Hence, the analgesic and anti-inflammatory action of DRK can be attributed to reduction of peripheral nociception by inhibition of prostaglandin release.

\section{Conclusions}

In summary, our present study has successfully elucidated the likely mechanism of antinociceptive and anti-inflammatory effect of Draksharishta. We have drawn a sound conclusion that DRK does not have any CNS-modulated effect in pain inhibition, based on three different in vivo models. Its peripheral analgesic activity has been also repeatedly confirmed by three in vivo models. Through this study, it is apparent that the mechanism of action of DRK is similar to that of the commonly used NSAIDs. Hence, its traditional use in arthritis, sciatia, and lumbago held the test of time, not by its mere placebo effect but by some potent analgesic and anti-inflammatory molecules hidden in this age-old Ayurvedic concoction. We believe further studies are required to elucidate the complete pharmacological profile of this potential analgesic preparation for safer and more effective use.

\section{References}

1. WHO. Media Centre: Fact Sheet. [Online] December 2008. Available from: http://www.who.int/mediacentre/factsheets/fs134/en/. [Last cited in 2012 May 18].

2. Firenzuoli F, Gor L. Herbal medicine today: Clinical and research issues. Evid Based Complement Alternat Med 2007;4:37-40.

3. Tyler VE. Herbal medicine: From the past to the future. Public Health Nutr 2000;3:447-52.

4. Bonica JJ. The need of a Taxonomy. Pain 1979;6:247-52.

5. Bromm B, Lorenz J. Neurophysiological evaluation of Pain. Electroencephalogr Clin Neurophysiol 1998;107:227-5.

6. Park H, Cha D, Jeon H. Antinociceptive and hypnotic properties of Celastrus orbiculatus. J Ethnopharmacol 2011;137:1240-4.

7. “Bangladesh National Formulary of Ayurvedic Medicine 2011”, $2^{\text {nd }}$ ed. Dhaka: Associates Printing Press; 2011.

8. Zimmerman M. Ethical guidelines for investigations of experimental pain in conscious animals. Pain 1983;16:109-10.

9. Franzotti EM, Santos CV, Rodrigues HM, Mourão RH, Andrade MR, Antoniolli AR. Anti-inflammatory, analgesic activity and acute toxicity of Sida cordifolia L. (Malva-branca). J Ethnopharmacol 2000;72:273-7.
10. Yang XY, Gao D, Pettus M, Phillips C, Bowersox SS. Interaction of intrathecally administered zinconotide, a selective blocker of neuronal N-type voltage- sensitive calcium channels, with morphone on nociception in rats. Pain 2000;84:271-81.

11. Olajide O, Awe SO, Makinde JM, Ekhelar AI, Olusola A, Morebise O, et al. Studies on the anti-inflammatory, antipyretic and analgesic properties of Alstonia boonei stem bark. J Ethnopharmacol 2000;71:179-86.

12. Damas J, Remacle-Volon G. Influence of a long-acting bradykinin antagonist, Hoe 140, on some acute inflammatory reactios in the rat. Eur J Pharmacol 1992;211:81-6.

13. Tjølsen A, Berge OG, Hunskaar S, Rosland JH, Hole K. The formalin test: An evaluation of the method. Pain 1992;51:5-17.

14. Kumar SV, Sandeep M, Kamal D, Nishnth BC, Megharaj HK, Kekuda TR, et al. Antibacterial and Anthelmintic activity of selected fermented Ayurvedic herbal formulations. Drug Invent Today 2010;2:347-8.

15. Chau TT. Analgesic testing in animal models. In: Pharmacological Methods in the Control of Inflammation. New York, NY: Alan R. Liss Inc; 1989. p. 195-212.

16. Cowan A. Recent approaches in testing analgesics in animals. In: Modern Methods in Pharmacology. New York, NY: Wiley-Liss Inc; 1990. p. 33-42.

17. Agyare C, Kuffuor GA, Boamah VE, Adu F, Mensah KB, Adu-Amoah L. Antimicrobial and Anti-inflammatory Activities of Pterygota macrocarpa and Cola gigentea (Sterculiaceae). Evid Based Complement Alternat Med 2012;65:1-9.

18. Amarlal JF, Silva MI, Neto MR, Neto PT, Moura BA, Melo CT, et al. Antinociceptive effect of the monoterpene R-(-)-limonene in mice. Biol Pharm Bull 2007;30:1217-20.

19. Dirig DM, Isakson PC, Yaksh TL. Effect of COX-1 and COX-2 inhibition on induction and maintainence of carrageenan-evoked thermal hyperalgesia in rats. J Pharmacol Exp Ther 1998;285:1031-8.

20. Dalal A, Tata M, Allegre G, Gekiere F, Bons N, Fessard DA. S pontaneous activity of rat dorsal horn cells in spinal segments of sciatic projection following transcetions of sciatic nerve or of corresponding dorsal roots. Neuroscience 1999;94:218-28.

21. Hunskaar S, Fasmer OB, Hole K. Formalin test in mice, a useful technique for evaluating mild analgesics. J Neutosci Methods 1985;14:69-76.

22. Brito AR, Antonio MA. Oral anti-inflammatory and anti-ulcerogenic activities of a hydroalcoholic extract and partitioned fractions of Turnera ulmifolia (Turneraceae). J Ethnopharmacol 1998;61:213-28.

23. Derardt R, Jougney S, Delevalcee F, Falhout M. Release of prostaglandins $\mathrm{E}$ and $\mathrm{F}$ in an algogenic reaction and its inhibition. Eur $\mathrm{J}$ Pharmacol 1980;80:17-24.

24. Bley KR, Hunter JC, Eglen RM, Smith JA. The role of IP prostanoid receptors in inflammatory pain. Trends Pharmaocl Sci 1998;19:141-7.

How to cite this article: Kabir A, Samad MB, D'Costa NM, Hannan JM. Investigation of the central and peripheral analgesic and anti-inflammatory activity of Draksharishta an Indian Ayurvedic formulation. J Basic Clin Pharma 2012;3:336-40.

Source of Support: The research was funded by Dept of Pharmacy, North South University, Conflict of Interest: No. 